\title{
Influence of Sources and Rates of Manure on Yield and Nutrient Uptake of Maize (Zea mays L.) in Maiduguri, Nigeria
}

\author{
1U.U. Waniyo, *2M.M. Sauwa, ${ }^{1}$ A.L. Ngala, ${ }^{2}$ G.A. Abubakar and ${ }^{1}$ E.C. Anelo \\ 1Department of Soil Science, Faculty of Agriculture, University of Maiduguri, Nigeria
}

2Dept. of Soil Science \& Agricultural Engineering, Faculty of Agriculture, Usmanu Danfodiyo University, Sokoto, Nigeria [Corresponding Author: Email mmsauwa4u@yahoo.com; 留: +2348060350495]

\begin{abstract}
Lack of proper knowledge on the type and exact quantity of manure required by crops are among the major constraints to maize production in Maiduguri. Thus a pot experiment was carried out in the screen house of University of Maiduguri to assess the effects of sources and rates of manure suitable for optimum maize production in Maiduguri, Borno State, Nigeria. The experiment was established as completely randomized design (CRD) with 4 manure treatments, 3 rates plus 3 controls (no manure), replicated 3 times. The results showed that, yield and nutrient uptake of maize was significantly $(p \leq 0.05)$ influenced by treatments at 21 and 42 days after planting (DAP). Cow manure treatment on average, produced the best of growth, yield and nutrient uptake (N,P, and $\mathrm{K}$ uptake) of maize compared to other treatments. Also, on average, values of most parameters in the 10 and $20 \mathrm{t} / \mathrm{ha}$ rates were statistically similar or higher than those of $30 \mathrm{t} / \mathrm{h} / \mathrm{ha}$. However, 10t/ha rate is considered more appropriate as it produces same effects as those of 20t/ha rates. From the results, it can be concluded that application of 10t/ha cow manure is adequate for optimum maize production in Maiduguri, North-Eastern Nigeria.

Keywords: Manure sources, Rates, Growth, Yield, Nutrient Uptake, Maize
\end{abstract}

\section{INTRODUCTION}

Maize (Zea mays L.) is an important crop in Nigeria mainly as an energy giving food. Based on cropped land and quantity produced, maize is Nigeria's third most important cereal crop after sorghum and millet (FAO,1996). Maize production in the sub Saharan Africa was reported to have an increasing trend of between 2-3 \% annually (Boxall, 2000) thereby making maize an important crop to the growth and sustenance of Nigeria's agricultural sector.

The performance of agricultural sector in Nigeria has over the decade remained far from expectations in terms of efficient crop production. Some of the factors militating against sufficient crop yield are more significantly scientific and technological, including the use of fertilizers (Udom et al., 2007). Most of the required nutrients for maize production are usually applied in form of inorganic fertilizers (Akintoye and Olaniyan, 2012). However, the high cost of inorganic fertilizers coupled with their inability to condition the soil has directed farmers attention to organic fertilization (Agyenim-Boateng et al., 2006).

Organic manure apart from supplying all essential nutrients required by plants, improve soil structure, aeration and encourage good root growth (Udom et al., 2007). Organic manures also enhance nitrogen availability, improve soil structure, water retention and increases soil organic matter (Ancheng and Sun, 1994). All these are essential for proper growth and yield of crops.

Therefore, the objective of the study was to evaluate the influence of different organic manures and rates on growth, yield and nutrient uptake of Maize.

\section{MATERIALS AND METHODS \\ Study Area}

The pot experiment was conducted during dry season of 2011 at University of Maiduguri, Faculty of Agriculture Screen House in other to evaluate the effect of manure sources and rates on growth, yield and nutrient uptake of maize. Climate of Maiduguri is semi arid, with long term mean annual rainfall of $553 \mathrm{~mm}$. Rainfall is unimodal, starting on average in mid-June and lasting till end of September (Grema and Hess, 1994). Soil used in the study is sandy loam classified as Typic ustipsamment (Rayar, 1984) having parent material of Aeolian sand.

\section{Treatments and Experimental Design}

The experiment was laid down in a completely randomized design (CRD) with 4 treatments (poultry, goat, sheep, and cow manure) and 3 rates (10,20 and 30 tha) plus 3 controls giving 15 treatments that were replicated 3 times giving a total of 45 treatments. The poultry manure used was poultry droppings from battery 
cage system. 10 seeds of maize were planted in each pot which was later thinned to 4 stands per pot.

\section{Soil and Plant Sampling}

Bulk soil was collected at a depth of $(0-20 \mathrm{~cm})$ at the University of Maiduguri Teaching and Research Farm, composited, air dried and kept for the experiment. Part of the air dried composited soil sample was screened through $2 \mathrm{~mm}$ sieve and kept for the determination of the physico-chemical properties of the soil before the experiment. $5 \mathrm{~kg}$ composited soil samples were weighed and placed in each plastic pot, and then treated with 4 organic manures (Poultry, Goat, Sheep and Cow) at 3 rates $(10,20$ and 30 tha) which resulted in the application of 25,50 and $75 \mathrm{~g}$ of manure per $5 \mathrm{~kg}$ soil in fertilized pots. 3 controls (no manure) were used for the experiment. The soil samples from each pot were not chemically analyzed at the end of the experiment due to some problems encountered. Plant (maize) samples were collected at 21 and 42 days after planting (DAP) and kept for the determination of growth, yield and nutrient uptake of the maize plant.

\section{Soil Analysis}

The screened composite soil samples collected before initiation of the pot experiment were used for the determination of physico-chemical properties of the soil. Texture of the soil was determined by hydrometer method (Gee and Bauder, 1986). The chemical properties of the soil samples were analyzed according to methods of Page et al. (1982). Electrical conductivity (EC) was determined using the conductivity meter, soil $\mathrm{pH}$ using $\mathrm{pH}$ meter, organic carbon by wet oxidation method, total nitrogen by micro kjeldahl procedure, available phosphorus by Bray-1 method, Exchangeable bases determined after extraction using ammonium acetate. Calcium (Ca) and Magnesium $(\mathrm{Mg})$ were determined by EDTA titration method, while potassium $(\mathrm{K})$ by flame photomet er.

\section{Plant Analysis}

Maize leaves collected from all pots (at 21 and 42 DAP) were chemically analyzed for nutrient uptake of maize. The leaf samples were oven dried at $65^{\circ} \mathrm{C}$ for $48 \mathrm{hrs}$ and grinded. Leaf nitrogen $(\mathrm{N})$ was determined using micro-kjeldahl digestion method. Part of the leaf samples collected were ashed at $500^{\circ} \mathrm{C}$ for 6 hrs in a furnance and extracted using $10 \% \mathrm{HCL}$ for the determination of $\mathrm{P}$ and $\mathrm{K}$. $\mathrm{P}$ was determined using vanadolmolybdate colorimetry, $\mathrm{K}$ using flame photometer(Tel and Hagarty, 1984).

\section{Determination of growth and yield parameters}

The experiment was conducted for a period of 42 days ( 6 weeks). At 21 days after planting (DAP), 2 stands out of the 4 stands of maize plant from each pot were carefully selected and growth and yield parameters namely: shoot length (SL), fresh weight (FW) and dry weight (DW) of maize plant were determined. SL was determined by measuring length of the maize plant from base to the tip using meter rule, while FW and DW (used as yield parameters of the maize plant) were determined after harvesting the maize plant by carefully uprooting it. The FW and DW yield parameters were then determined by weighing the 2 maize stands from each pot using weighing balance. The same was done for the remaining 2 stands of maize plant at 42 DAP.

\section{Statistical Analysis}

Results obtained were analyzed using statistix 8.0 software version 2005 (for analysis of varianceANOVA) and means were separated using least significant difference (LSD) test at $5 \%$ level of probability using the same software.

\section{RESULTS AND DISCUSSION}

\section{Physico-Chemical Properties of the Soil}

Table 1 shows that the soil used for the study is neutral with no danger of salinity, but low in organic carbon $(\mathrm{OC})$, total nitrogen $(\mathrm{N})$, Magnesium $(\mathrm{Mg})$ and moderate in potassium $(K)$. This means response to both organic and inorganic amendments is highly anticipated.

Table 1: Physico-Chemical Properties of Soil Used

\begin{tabular}{lc}
\hline \multicolumn{1}{c}{ Parameters } & Values \\
\hline $\mathrm{pH}\left(\mathrm{H}_{2} \mathrm{O}, 1: 2.5\right)$ & 6.71 \\
$\mathrm{EC}\left(\mu \mathrm{s} / \mathrm{cm}^{-1}\right)$ & 11.50 \\
Organic carbon $(\mathrm{g} / \mathrm{kg})$ & 4.40 \\
$\mathrm{~N}(\mathrm{~g} / \mathrm{kg})$ & 0.50 \\
$\mathrm{P}(\mathrm{g} / \mathrm{kg})$ & 5.30 \\
$\mathrm{~K}(\mathrm{~g} / \mathrm{kg})$ & 4.45 \\
$\mathrm{Mg}(\mathrm{cmol} / \mathrm{kg})$ & 2.6 \\
$\mathrm{Ca}(\mathrm{cmol} / \mathrm{kg})$ & 3.6 \\
Sand $(\mathrm{g} / \mathrm{kg})$ & 700 \\
Silt $(\mathrm{g} / \mathrm{kg})$ & 150 \\
Clay $(\mathrm{g} / \mathrm{kg})$ & 150 \\
Texture & Sandy loam \\
\hline
\end{tabular}

Table 2 shows the chemical composition of manures used. It shows that poultry manure has the highest 
nitrogen $(N)$ and phosphorus $(P)$ content while cow manure has the least content of $\mathrm{N}, \mathrm{P}$ and $\mathrm{K}$.

Table 2: Chemical composition of manures used

\begin{tabular}{llll}
\hline Sample & $\% \mathrm{~N}$ & $\% \mathrm{P}$ & $\% \mathrm{~K}$ \\
\hline Cow & 0.34 & 0.13 & 1.25 \\
Sheep & 0.43 & 0.29 & 3.0 \\
Goat & 0.57 & 0.23 & 1.63 \\
Poultry & 0.64 & 0.33 & 2.3 \\
\hline
\end{tabular}

Influence of sources and rates of manure on shoot length, fresh weight and dry weight of Maize

Table 3 shows the results of the influence of sources and rates of manure on growth performance and yield of maize. The results reveals that manure sources and rates significantly $(p \leq 0.05)$ influenced shoot length (SL), fresh weight (FW) and dry weight (DW) of maize at 21 and 42 DAP. The results revealed that at 21 days after planting (DAP) for the 10t/ha rate, the highest shoot length (SL) $61.80 \mathrm{~cm}$ was recorded when $10 \mathrm{t} / \mathrm{ha}$ cow manure was applied, while the least $S L 37.83 \mathrm{~cm}$ was recorded when sheep manure was used. Similarly, at 20 t/ha manure rate, cow manure treatment had the highest SL of $64.33 \mathrm{~cm}$ while the least SL 38.67 was recorded when goat manure was applied. The 30 tha rate followed similar trend in SL as that of 20 tha rate (Table 3). For shoot length (SL) at 42 DAP at the 10 tha manure rate, goat manure has the highest SL of $96.00 \mathrm{~cm}$ while sheep manure recorded the least SL $(67.67 \mathrm{~cm})$. However, at the 20 tha rate, cow manure gave the highest SL $100.67 \mathrm{~cm}$ while control treatment showed the least SL (Table 3). Similar result as that of 20t/ha on SL was observed at 30 t/ha rate of manure application although goat manure recorded the least SL value (Table 3).

The influence of sources and rates of manure on shoot length at different stage of plant growth is significant ( $p$ $\leq 0.05$ ) Table 3 . It is evident from Table 3 that, maximum production of shoot length was recorded when cow manure was applied. This could be attributed to the release of nutrient elements such as nitrogen $(\mathrm{N})$, phosphorus $(\mathrm{P})$ and potassium $(\mathrm{K})$ by organic manure upon decomposition that aids growth and yield of crops. Jones (1993) reported significant increase in yield components of maize crop due to organic fertilization and attributed it to the supply of essential nutrients especially $\mathrm{N}, \mathrm{P}, \mathrm{K}$ and $\mathrm{S}$ by organic manures. Further, the appreciable increase in shoot length observed from 21 DAP to 42 DAP may be due to the increased rate of mineralization of the manure and assimilation of the slowly released nutrients by the maize plant.

Sources and rates effects on fresh weight (FW) of maize plant at 21 DAP and 42 DAP were significant $(p \leq 0.05)$ Table 3 . The results reveals that, cow manure gave the highest FW value of $10.27 \mathrm{~g}$ at 21 DAP for 10 tha manure rate while the least value (3.33g) was obtained when sheep manure was applied Table 3. Conversely, at 20 tha rate sheep manure treatment recorded the highest FW (9.37g) while goat manure gave the least FW value (3.43g). At 30 tha rate, the highest FW $9.97 \mathrm{~g}$ was obtained when cow manure was used while lowest value $(3.07 \mathrm{~g})$ was observed with application of goat manure (Table 3). Results of manure sources and rates effects on maize fresh weight (FW) at 42 DAP at 10 t/ha rate shows that, goat and cow manures had the highest FW values (65.73g and 65.47g) respectively, while control and sheep manure treatments gave the least values (Table 3). At the 20 tha rate, sheep manure had the highest FW $(70.47 \mathrm{~g})$ while least value $(29.80 \mathrm{~g})$ was recorded in control treatment. However, at 30 tha rate, cow manure application gave highest FW value of $75.33 \mathrm{~g}$ as control treatment showed the least FW value $(29.23 \mathrm{~g})$ Table 3. Averagely, 42 DAP FW values were higher than those of 21 DAP and 10 tha as well as 20 tha rate values are statistically comparable with or higher than those of 30 t/ha irrespective of manure source. The higher fresh weight (FW) values at 42 DAP than 21 DAP could be related to increased rate of mineralization of organic manures over time. Generally, the increased FW values in fertilized pots could be related to enhancement of physical and chemical properties of the the soil such as enhanced nutrient elements availability, increased available moisture content, decreased bulk density (BD) and increased total porosity (TP), likewise enhanced activities of beneficial microorganisms due to manure application.. This is in agreement with findings of Tisdale et al. (1985) that organic manure, apart from supplying nitrogen and other elements, increases available moisture content of soils, improved BD and aeration likewise enhancing beneficial microbial activities.

Manure sources and rates also significantly ( $p \leq 0.05$ ) influenced dry weight (DW) of maize plant at 21 and 42 DAP (Table 3). At 21 DAP, for the 10 tha rate, cow manure recorded highest DW $(1.94 \mathrm{~g})$ while the least value was obtained when sheep manure was applied $(0.52 \mathrm{~g})$. However, sheep manure had the highest DW 
at 20 tha rate $(1.49 \mathrm{~g})$ while goat manure recorded the least $(0.50 \mathrm{~g})$. On the other hand, at $30 \mathrm{t} / \mathrm{ha}$ rate, cow manure treatment gave the highest DW $(1.59 \mathrm{~g})$ while goat manure recorded the least $(0.47 \mathrm{~g})$ Table 3 . For 42 DAP at 10 tha, the highest DW value of $28.42 \mathrm{~g}$ was obtained with application of cow manure, while the least value $(11.50 \mathrm{~g})$ was obtained in control treatment Table 3. Also, at 20 tha rate, cow manure treatment had the highest DW (30.42g) and the least DW value was recorded by control treatment $(14.42 \mathrm{~g})$. In similar vain, at 30 tha rate for the 42 DAP period, goat manure obtained the highest maize DW value $(30.24 \mathrm{~g})$ while control had the least (11.20g) Table 3. The increase in maize DW observed in organically fertilized plots could also be attributed to improvement in physical and chemical properties of the soil as reported by Udom et al. (2007) that, organic manures supply nutrients to plants, improve soil structure, aeration and encourages good root growth which may invariably had resulted in increased growth and yield of the maize plant. Similarly, Chiroma et al. (2005) added that, decomposition of organic materials (wood chips mulch) could lead to increased amount of oxidisable organic matter and nutrient contents in the surface layers of organically amended plots.
It can be deduced from Table 3 that, although significant effects of manure sources and rates on SL, FW and DW of the maize plant are not consistent with a particular manure or rate, on average, there was a trend of increasing SL, FW and DW of maize plant at both 21 and 42 DAP due to application of cow manure, likewise 10 and 20 t/ha rate values been significantly higher than / statistically similar to those of 30 tha rate. This suggest the superiority of cow manure in improving growth and yield of maize and suitability of 10 and 20t/ha rate for improving maize yield in the experimental area. The increased growth and yield of maize plant observed due to cow manure application could be related to ease of mineralization of the cow manure compared to other manures, that might have resulted in greater improvement of the physical and chemical properties of the soil likewise growth and yield of the maize plant. Jama et al. (2000) and Udom et al. (2007) both reported increased yield and yield components of maize due to organic fertilization and related it to enhancement of soil properties such as decreased bulk density, improved moisture storage, increased organic matter contents likewise enhanced cations concentration.

Table 3: Influence of rate and sources of manure on shoot length (SL), Fresh (FW) and dry (DW) weight of maize at 21DAP and 42DAP

\begin{tabular}{|c|c|c|c|c|c|c|c|}
\hline \multirow[b]{2}{*}{ Treatment } & \multicolumn{3}{|c|}{21 DAP } & \multicolumn{4}{|c|}{42 DAP } \\
\hline & Rate & SL (cm) & FW (g) & DW (g) & $\mathrm{SL}(\mathrm{cm})$ & FW (g) & DW (g) \\
\hline \multirow[t]{3}{*}{ Control } & 0 tha & $45.33^{a-c}$ & $5.17 \mathrm{c}-\mathrm{f}$ & $0.93^{b c}$ & $78.33^{b-d}$ & $23.53 e$ & $11.50^{d}$ \\
\hline & 0 tha & $49.33^{a-c}$ & $7.60^{a-c}$ & $1.28^{a-c}$ & $76.67^{\mathrm{b}-d}$ & $29.80^{\text {de }}$ & $14.42^{c d}$ \\
\hline & 0 tha & $50.00^{a-c}$ & $5.44 c-f$ & $1.02^{a-c}$ & $66.67^{d}$ & 29.23 de & $11.20^{d}$ \\
\hline \multirow[t]{3}{*}{ Cow manure } & $10 \mathrm{t} / \mathrm{ha}$ & $61.80^{a}$ & $10.27^{a}$ & $1.94^{a}$ & $94.70^{a-c}$ & $65.47 \mathrm{ab}$ & $28.42^{\mathrm{ab}}$ \\
\hline & 20 t/ha & $64.33^{a}$ & $8.00^{a-d}$ & $1.31^{a-c}$ & $100.67^{\mathrm{a}}$ & $60.03^{a b}$ & $30.42^{\mathrm{ab}}$ \\
\hline & 30 t/ha & $60.33^{a}$ & $9.97 \mathrm{ab}$ & $1.59 \mathrm{ab}$ & $100.3^{a}$ & $75.33^{a}$ & $26.33^{a b}$ \\
\hline \multirow[t]{3}{*}{ Goat manure } & 10 t/ha & $57.00^{\mathrm{ab}}$ & $9.23^{a-c}$ & $1.19 a-c$ & $96.00^{\mathrm{ab}}$ & $65.73^{a b}$ & $18.80^{b-d}$ \\
\hline & 20 t/ha & $38.67 c$ & $3.43^{\mathrm{ef}}$ & $0.50 c$ & $97.33^{a b}$ & $73.33^{a}$ & $26.22^{a b}$ \\
\hline & $30 \mathrm{t} / \mathrm{ha}$ & $38.17 \mathrm{c}$ & $3.07^{\dagger}$ & $0.47 c$ & $92.33^{a-c}$ & $56.63^{a-c}$ & $30.24^{b-d}$ \\
\hline \multirow[t]{3}{*}{ Sheep manure } & $10 \mathrm{t} / \mathrm{ha}$ & $37.83^{c}$ & $3.33^{\mathrm{ef}}$ & $0.52^{c}$ & $67.67^{d}$ & $32.24 c-e$ & $13.93^{\mathrm{cd}}$ \\
\hline & 20 t/ha & $57.00^{\mathrm{ab}}$ & $9.37^{a-c}$ & $1.49^{a b}$ & $93.23^{a-c}$ & $70.47^{\mathrm{a}}$ & $28.10^{\mathrm{ab}}$ \\
\hline & 30 t/ha & $40.83^{b c}$ & $3.80^{d-f}$ & $0.78^{b c}$ & $83.03^{a-d}$ & $63.9^{\mathrm{ab}}$ & $28.10^{\mathrm{ab}}$ \\
\hline \multirow[t]{3}{*}{ Poultry manure } & 10 t/ha & $53.83^{a-c}$ & $6.83^{a-f}$ & $1.49 \mathrm{ab}$ & $74.40^{\mathrm{cd}}$ & $50.90^{a-d}$ & $13.31^{\mathrm{cd}}$ \\
\hline & 20 t/ha & $51.17^{a-c}$ & $4.50^{\mathrm{d}-f}$ & $1.34^{a-c}$ & $87.30^{a-d}$ & $41.41^{\text {bee }}$ & $23.10^{a-c}$ \\
\hline & $30 \mathrm{t} / \mathrm{ha}$ & $51.00^{a-c}$ & $5.53^{b-f}$ & $0.98 \mathrm{bc}$ & $94.33^{a-c}$ & $56.32^{a-c}$ & $22.83^{a-c}$ \\
\hline LSD $(0.05)$ & & 17.8 & 4.49 & 0.94 & 20.7 & 26.4 & 10.5 \\
\hline
\end{tabular}


Influence of sources and rates of manure on nitrogen, phosphorus and potassium uptake of maize

The results of the influence of sources and rates of manure on nutrient uptake of maize plant at 21 and 42 days after planting (DAP) are shown in Table 4. Manure treatments significantly $(p \leq 0.05)$ influenced nutrient uptake of maize plant. It was observed that at the rate of $10 \mathrm{t}$ /ha addition of manure, the nitrogen $(\mathrm{N})$ uptake in maize plant at 21 DAP was highest $(0.19)$ in poultry manure while cow manure recorded the least. Conversely, at the rate of 20 tha manure at 21 DAP, the $\mathrm{N}$ uptake by maize plant was higher $(0.18)$ in cow manure and control treatments, while poultry manure gave the least $\mathrm{N}$ uptake (0.14) Table 4. However, at 30 tha rate for the 21 DAP growth period, poultry manure had the highest $\mathrm{N}$ uptake $(0.20)$ while the least was found in sheep manure treatment (0.13) Table 4. At 42 DAP growth period for the 10 t/ha organic manure rate, the $\mathrm{N}$ uptake was highest $(0.18)$ in cow manure treatment and the least (0.15) was recorded by control, sheep and poultry manure treatments (Table 4).

In a similar vain, at the 20 tha manure rate, the least (0.14) N uptake was obtained in control and sheep manure treatments while goat manure gave the highest
(0.22) $\mathrm{N}$ uptake. The $30 \mathrm{t} / \mathrm{ha}$ rate of application shows that the highest $\mathrm{N}$ uptake (0.21) was recorded when cow manure was applied, and the least (0.15) was obtained in control and goat manure treatments (Table 4). It can be deduced from Table 4 that, manure sources and rates significantly ( $p \leq 0.05$ ) influenced $N$ uptake of maize plant at both 21 and 42 DAP. A comparative analysis of the influence of manure sources on maize $\mathrm{N}$ uptake showed that, $\mathrm{N}$ uptake at the various stages of maize plant growth (21 and 42 DAP) were similar (Table 4).

Values of phosphorus $(P)$ uptake in maize plant at 21 and 42 DAP presented in Table 4 revealed that, manure sources and rates also significantly $(p \leq 0.05)$ influenced $P$ uptake of maize. At 10 tha rate for the 21 DAP growth stage, the highest $P$ uptake $(0.20)$ was obtained when cow manure was used while the least (0.04) was recorded with application of poultry manure. Also values of $P$ uptake at 20 tha rate and 21 DAP growth stage shows that sheep manure treatment had the highest (0.25) $P$ uptake while the least $(0.03)$ was portrayed by poultry manure (Table 4). Similarly, at 30 tha rate and 21 DAP, poultry manure recorded the least $P$ uptake $(0.01)$ while highest value $(0.11)$ was found in control treatment.

Table 4: Influence of rate and sources of manure on Nitrogen $(N)$, Phosphorus $(P)$ and Potassium $(K)$ uptake by maize at 21DAP and 42DAP

\begin{tabular}{|c|c|c|c|c|c|c|c|}
\hline \multirow[b]{2}{*}{ Treatment } & \multirow[b]{2}{*}{ Rate } & \multicolumn{3}{|c|}{21 DAP } & \multicolumn{3}{|c|}{42 DAP } \\
\hline & & $\mathrm{N}(\%)$ & $P(\%)$ & $\mathrm{K}(\%)$ & $\mathrm{N}(\%)$ & $P(\%)$ & $\mathrm{K}(\%)$ \\
\hline \multirow[t]{3}{*}{ Control } & $0 \mathrm{t} / \mathrm{ha}$ & $0.15^{a-c}$ & $0.05^{\text {de }}$ & $2.29^{b-d}$ & $0.15^{b c}$ & $1.27^{\mathrm{d}-f}$ & $16.85^{f}$ \\
\hline & $0 \mathrm{t} / \mathrm{ha}$ & $0.18^{a-c}$ & $0.04^{\mathrm{de}}$ & $2.80^{b-d}$ & $0.14^{c}$ & $1.41^{\mathrm{d}-\mathrm{f}}$ & $28.23^{\mathrm{d}-\mathrm{f}}$ \\
\hline & 0 t/ha & $0.18^{a-c}$ & $0.11^{c-e}$ & $2.02^{c-d}$ & $0.15^{b c}$ & $1.14^{\mathrm{d}-\mathrm{f}}$ & $19.13^{\mathrm{d}-\mathrm{f}}$ \\
\hline \multirow[t]{3}{*}{ Cow manure } & $10 \mathrm{t} / \mathrm{ha}$ & $0.14^{b c}$ & $0.20^{a b}$ & $5.63^{a}$ & $0.18^{a-c}$ & $0.52^{\mathrm{ef}}$ & $40.62^{b-f}$ \\
\hline & $20 \mathrm{t} / \mathrm{ha}$ & $0.18^{a-c}$ & $0.24^{a}$ & $4.13^{a-c}$ & $0.19 a-c$ & $4.56^{a}$ & $59.56^{a-c}$ \\
\hline & 30 t/ha & $0.19 a-c$ & $0.10^{c-e}$ & $3.81^{a-c}$ & $0.21^{\mathrm{ab}}$ & $0.28^{f}$ & $64.10^{\mathrm{ab}}$ \\
\hline \multirow[t]{3}{*}{ Goat manure } & $10 \mathrm{t} / \mathrm{ha}$ & $0.18^{a-c}$ & $0.18^{a-c}$ & $3.54^{a-d}$ & $0.17^{a-c}$ & $2.83^{b c}$ & $27.82^{\mathrm{d}-\mathrm{f}}$ \\
\hline & $20 \mathrm{t} / \mathrm{ha}$ & $0.17^{a-c}$ & $0.08^{c-e}$ & $1.16^{d}$ & $0.22^{\mathrm{a}}$ & $3.02^{b c}$ & $58.50^{\mathrm{a}-\mathrm{c}}$ \\
\hline & $30 \mathrm{t} / \mathrm{ha}$ & $0.14^{b c}$ & $0.05^{\mathrm{d}-\mathrm{e}}$ & $1.22^{d}$ & $0.15 b c$ & $2.24^{b-d}$ & $72.50^{a}$ \\
\hline \multirow{3}{*}{ Sheep manure } & $10 \mathrm{t} / \mathrm{ha}$ & $0.17^{a-c}$ & $0.13^{b-d}$ & $1.39 \mathrm{~d}$ & $0.15^{b c}$ & $0.86^{d-f}$ & $18.23^{e f}$ \\
\hline & $20 \mathrm{t} / \mathrm{ha}$ & $0.15^{a-c}$ & $0.25^{\mathrm{a}}$ & $4.17^{a-c}$ & $0.14^{c}$ & $0.29^{f}$ & $42.93^{b-e}$ \\
\hline & $30 \mathrm{t} / \mathrm{ha}$ & $0.13^{c}$ & $0.04^{\mathrm{de}}$ & $2.51^{b-d}$ & $0.20^{a-c}$ & $3.52^{a b}$ & $44.60^{b-d}$ \\
\hline \multirow[t]{3}{*}{ Poultry manure } & $10 \mathrm{t} / \mathrm{ha}$ & $0.19 a-c$ & $0.04^{\mathrm{de}}$ & $4.55^{\mathrm{ab}}$ & $0.15^{b c}$ & $1.74^{c-e}$ & $35.70^{c-f}$ \\
\hline & 20 t/ha & $0.14^{\mathrm{bc}}$ & $0.03^{\mathrm{de}}$ & $2.81^{b-d}$ & $0.16^{a-c}$ & $0.85^{d-f}$ & $56.27^{a-c}$ \\
\hline & $30 \mathrm{t} / \mathrm{ha}$ & $0.20^{a}$ & $0.01 \mathrm{e}$ & $2.19^{b-d}$ & $0.18^{a-c}$ & $1.38^{d-f}$ & $55.73^{a-c}$ \\
\hline LSD (0.05) & & 0.06 & 0.11 & 2.39 & 0.06 & 1.42 & 25.5 \\
\hline
\end{tabular}

a-f : means values followed by the same letter (s) in the same column are not significantly different at $p \leq 0.05$ level of probability DAP : Days after planting 
$P$ uptake at 42 DAP growth stage and 10 t/ha manure rate revealed that the highest $P$ uptake (2.83) was recorded by goat manure treatment and the least $(0.52)$ was found in cow manure (Table 4). However, at 20 tha rate of application for the 42 DAP growth stage, cow manure treatment gave the highest $P$ uptake (4.56) while sheep manure recorded the least $P$ uptake (0.29). Conversely, at 30 tha rate for the 42 DAP growth period, the least $P$ uptake value $(0.28)$ was obtained when cow manure was applied while the highest (3.52) was obtained in sheep manure (Table 4). The observed low $P$ uptake values at the various growth stages (21 and 42 DAP) particularly at 21 DAP of the maize plant could be due to the low $P$ content of the savannah soil of the study area.

Results of the influence of rates and sources of manure on potassium (K) uptake are also presented in Table 4. The results revealed that, $\mathrm{K}$ uptake at both 21 and 42 DAP was significantly ( $p \leq 0.05)$ influenced by sources and rates of manure. At 10 t/ha rate and 21 DAP growth stage, cow manure had the highest $K$ uptake (5.63) while the least (1.39) was obtained in sheep manure treatment (Table 4). However, sheep manure treatment had the highest $\mathrm{K}$ uptake (4.17) at 20 tha rate for the 21 DAP growth stage, while lowest value (1.16) was portrayed by goat manure. Further, at 30 tha rate of organic manure application for 21 DAP, the $\mathrm{K}$ uptake of maize was highest in cow manure treatment (3.81) while the least (1.22) was recorded by goat manure (Table 4).

In a similar vain, values of $\mathrm{K}$ uptake for 42 DAP growth stage also shows significant $(p \leq 0.05)$ influence of treatments on $\mathrm{K}$ uptake (Table 4$)$. The results revealed that, at the rate of $10 \mathrm{t} / \mathrm{ha}$ manure application, the highest $\mathrm{K}$ uptake (40.62) was found in cow manure while control treatment recorded the least (16.85). Similarly, at $20 \mathrm{t} / \mathrm{ha}$ rate, for the 42 DAP growth stage, cow manure treatment had the highest $(59.56) \mathrm{K}$ uptake while control treatment also portrayed the least $\mathrm{K}$ uptake (28.23) Table 4. Similar pattern also follows at 30 tha rate of manure application where the least $\mathrm{K}$ uptake value (19.13) was found in control treatment while goat manure recorded the highest $(72.50) \mathrm{K}$ uptake (Table 4). The low $\mathrm{K}$ uptake values observed at 21 DAP could be due to the moderate $\mathrm{K}$ content of the soil which had been reported to be characteristic of savannah soils of north eastern Nigeria (Jones, 1971). However, K uptake values at later growth stage of maize plant (42 DAP) were higher which could be attributed to accumulation of mineral nutrients in the soil that were slowly released by the manure as a result of decomposition through microbial action. This is in conformity with the findings of Akintoye and Olaniyan (2012) that organic fertilizers release nutrients slowly.

It is not clear why some nutrient uptake values were higher in control treatment than manure treated pots, however, on average, nutrient uptake of maize plant were higher in manure treated pots compared to the control. This could be attributed to the release of nutrients by the organic manures upon decomposition and their absorption by the maize plant. Chiroma et al. (2006) made similar observations on leaf nutrient (N, P, $\mathrm{K}, \mathrm{Ca}$ and $\mathrm{Mg}$ ) contents of sorghum in the experimental area. In addition, nutrient uptake (particularly $\mathrm{P}$ and $\mathrm{K}$ uptake) were greater at 42 DAP than 21 DAP which could also be linked to increased availability of nutrients as a result of enhanced decomposition of organic manures as growth period progressed. Further, cow manure treatment demonstrated significant influence on nutrient uptake of maize irrespective of rate of application. By and large, on average, 10 and 20 tha rates of application values were statistically similar to /higher than those of $30 \mathrm{t} / \mathrm{ha}$ rate. This suggests the appropriacy of 10 and 20 t/ha manure rates for better yield of maize plant (been more economically viable than 30t/ha rate) in coarse textured soils of north eastern Nigeria.

\section{CONCLUSION}

The study revealed that there was a positive response of maize crop to treatments tested and that good growth, yield and nutrient uptake of maize is promoted with the application of 10 or 20 t/ha cow manure as evidenced by an increase in above ground biomass. However, considering the cost of transportation of large volume of manures, 10t/ha rate seems more economically viable. From the results, it can be inferred that, application of 10t/ha cow manure is adequate for optimum maize production in the area. It is however recommended that, soil testing should be carried out from time to time to know soil fertility level and recommended manure rate to apply. In addition, the same treatments should be tested on other crops to compare results.

\section{REFERENCES}

Agyenim-Boateng, S., Zickermann, J. and Kornahrens, M. (2006). Poultry manure effect on growth and 
yield of maize. West African Journal of Applied Ecology, 9: 1-11.

Akintoye, H.A. and Olaniyan, A.B. (2012). Yield of sweet corn in response to fertilizer sources. Global Advance Research Journal of Agricultural Science, 1(5): 110-116.

Ancheng, L. and Sun, X. (1994). Effect of organic manure on the biological activities associated with insoluble phosphorus release in a blue purple paddy soil. Communication of Soil Science and Plant Analysis, 25: 2513 - 2522.

Boxall, R.A. (2000). Post harvest technology of quality protein maize: Storage and Processing. Choosing the right technology. Final report. Chatham U.K. NRI. Pp 44.

Chiroma, A.M., Alhassan, A.B. and Yakubu, H. (2006). Growth, nutrient composition and straw yield of sorghum as affected by land configuration and wood-chips mulch on a sandy loam soil in Northeast Nigeria. International Journal of Agriculture and Biology, 8(6): 770-773.

Chiroma, A.M., Folorunso, O.A. and Kundiri, A.M. (2005). Effects of tillage and stubble management on root growth and water use of millet grown on a sandy loam soil. Journal of Arid Agriculture, 15: 83-89.

FAO (1996). Quarterly Bulleting of statistics. Food and agricultural organization of the United Nation Rome, Italy. Pp 8.

Gee, G.W. and Bauder, J.W. (1986). Particle size analysis In: Klute, A. (Ed). Method of soil Analysis, Part 1. Physical and mineralogica I properties. Agronomy monograph 9. American Society of Agronomy, Madison, Wisconsin. pp383- 411.

Grema, A.K. and Hess, T.M. (1994). The impact of changing rainfall patterns on the efficiency of rainfall utilization in pearl millet-cowpea intercropping systems in Northeast Nigeria. Aspects of Applied Biology, 38: 231 - 238.
Jama, B., Swinkels, R.A. and Bunish, R.J. (2000). Agronomic and economic evaluation of organic fertilizer. Mimeo. Ministry of Agriculture. Agricultural Section Development Strategies, Nairobi, Kenya.

Jones, M.J. (1971). The maintenance of soil organic matter under continuous cultivation at Samaru, Nigeria. Journal of Agricultural Science, 77: 473482.

Jones, H.K. (1993). A Survey of the availability of tissue nitrogen and phosphorus concentration in maize and grain sorghum. Field Crop Research, 6: 133-137.

Page, A.L., Miller, R.H. and Keeney, D.R. (1982). Methods of soil Analysis, part 2. Chemical and mineralogical properties. Agronomy monograph 9. American Society of Agronomy - Soil Science Society of America. Madison, Wisconsin.

Rayar, A.J. (1984). University of Maiduguri farm development planning report for faculty of Agriculture, Annex A; Soil Survey Details.

Statistix 8.0 (2005). Ststistix 8.0 (Version 2005), statistix for windows analytical Software, USA.

Tel, D.A. and Hagarty, M. (1984). Soil and Plant Analysis. International Institute of Tropical Agriculture (IITA)/University of Guelph, Ontario, Canada. Pp 277.

Tisdale, S.L., Nelson, W.L. and Beaton, J.D. (1985). Soil Fertility and Fertilizers. In: Nyangani, E.T. (2010). Effect of combined application of organic manure and chemical fertilizers on soil properties and crop yields (A Review). Nigerian Journal of Science, Technology and Environmental Education 3(1): 28-32.

Udom, N.G., Fagam, A.S. and Bello, H.M. (2007). Effect of poultry litter on the yield of two maize varieties in the Nigerian savanna. Continental Journal of Agronomy, 1:18-24. 